\title{
15. BASAL FERROMANGANOAN SEDIMENTS AT DSDP SITE 183, ALEUTIAN ABYSSAL PLAIN, AND SITE 192, MEIJI GUYOT, NORTHWEST PACIFIC, LEG 19
}

\author{
James H. Natland, Scripps Institution of Oceanography, La Jolla, California
}

\begin{abstract}
Basal sediments cored above alkali basalt at Site 183 beneath the Aleutian Abyssal Plain include iron-rich clays, a geothitebearing calcareous ironstone $\left(23.8 \% \mathrm{Fe}\right.$ and $4.16 \% \mathrm{Mn}, \mathrm{CaCO}_{3}$ free), and a pyrite-bearing unfossiliferous aragonitic limestone with 1.95 per cent Sr. The diversity of facies is similar to that of Red Sea sediments cored in deeps filled with hot metallogenic brines. The comparison is strengthened by the limestone since the Red Sea is the only other locale where deep marine indurated aragonitic limestones have been reported, apparently associated with the hot metal-rich brines. Experimental evidence verifies that aragonite is the only $\mathrm{CaCO}_{3}$ polymorph precipitated from carbonate-saturated seawater above $30^{\circ} \mathrm{C}$. In the deep sea, aragonite formed in surface waters usually dissolves before reaching bottom, or, once there, inverts to calcite. The $\mathrm{Sr}$ concentration in the Site 183 limestone is about twice as high as that in aragonite produced experimentally from seawater or as found in typical shallow-marine occurrences. These relations imply that the Site 183 limestone precipitated from a nearbottom, $\mathrm{Sr}$ - and metal-rich brine, possibly well above bottom water temperatures.

At Hole 192A, atop Meiji Guyot, the northernmost of the Emperor Seamounts, five meters of iron and manganese-enriched clays interlayered and diluted with chalk lie on extrusive alkali basalt pillow lavas beneath almost a kilometer of silts, clays, and diatomaceous oozes. The metal-bearing clays seem related to the intensely altered volcanics in which much of the glassy groundmass and almost all of the intergranular material in the diabasic portions have been replaced by clays and calcite. The alteration is most intense in zones adjacent to abundant cracks and joints which are filled with calcite and ferromanganese oxides throughout the several meters of volcanics recovered. The sediment-basalt interface is marked by recrystallized calcite and ferruginous clays sharply enriched in $\mathrm{Mn}$ and $\mathrm{Zn}$ compared to red clays only a meter higher. The field and textural relations of the volcanics plus the presence of iron oxides with relatively high $\mathrm{Mn}, \mathrm{Cu}$, and $\mathrm{Zn}$ in crack fillings deep in the volcanics, suggest that metals were emplaced in the sediments diagenetically after being leached from the volcanics during their alteration.

Basal sediments at both Site 183 and Hole 192A were recovered above seamount related volcanics and do not reflect ocean rise hydrothermal activity. Site 183 offers the best evidence yet that hot brines can exist in the open ocean, but Hole $192 \mathrm{~A}$ is clear evidence that hot brines are not necessary to explain all metal-rich deep marine basal sediments.
\end{abstract}

\section{INTRODUCTION}

Dark brown and orange red metal-enriched basal sediments were cored on Leg 19 at Site 183 beneath the Aleutian Abyssal Plain and at Site 192 atop Meiji Guyot, the northernmost of the Emperor Seamounts. The Site 183 sediments probably precipitated from near-bottom metalbearing, possibly warm brines while the Site 192 sediments seem related to low-temperature alteration of the underlying volcanic rocks. This report, encompassing shore-based
X-ray, petrographic, and chemical studies on the sediments, outlines these conclusions.

\section{SITE 183 LITHOLOGIES}

Core 39 of Site 183 underlies 500 meters of pelagic sediments and turbidites and represents 1.5 meters of 5 meters cored. The interval between 481 meters and 500 meters was not cored, but some of the sediments of Core 39 may be from that interval if they were not washed 
through during coring operations. The final half-meter of pelagic and metal-rich sediments may thus represent up to 23 meters of section. Most of the first meter of Core 39 is dark gray silty clay identical to that cored above 481 meters in Core 38. This is followed by these facies:

1) Dusky yellow clay, $10 \mathrm{~cm}$;

2) Bluish white nannofossil limestone, middle Eocene in age, $5 \mathrm{~cm}$;

3) Dark yellow brown ferruginous clay, $7 \mathrm{~cm}$;

4) Orange calcareous ironstone, $8 \mathrm{~cm}$;

5) Gray-green indurated limestone, $7 \mathrm{~cm}$; and

6) Olivine basalt.

All facies occur as separate sub-rounded chunks; no transitions or contacts are preserved.

\section{THIN SECTION DESCRIPTIONS AND MINERALOGY}

Thin sections were prepared from the basalt, gray green indurated limestone, and the "ironstone". Photomicrographs of filled cracks in the basalt, of the limestone, of an altered basalt glass inclusion in the limestone, and of the ironstone are shown on Plate 1, Figures 1 through 4. Mineralogic determinations were made optically or by $\mathrm{X}$-ray powder diffraction techniques.

The basalt is described in detail in an appendix attached to the site chapters and also in Stewart and others, this volume. The pieces recovered were fresh except for slight darkening in color next to cracks. One piece had a $1-\mathrm{cm}$, highly cracked, chilled, glassy rind. In thin section, the sideromelane is clear, brown and generally free of alteration materials. The rock has about 5 per cent olivine microphenocrysts, while the groundmass contains olivine partly altered to iddingsite, and variolitic clinopyroxene, highly clouded with opaque iron oxides. Feldspar is absent. Vesicles are rare and tiny $(<0.1 \mathrm{~mm})$. Chemically the rock is an alkali basalt (Stewart and others, this volume, Table 1).

Minerals filling cracks in the basalt are calcite, poorlydiffracting orange iron oxides, sodium harmotome (a phillipsite-like zeolite), montmorillonite probably nontronite or saponite, and pyrite. Plate 1, Figure 1, shows a crack lined with a fine fibrous pale brown clay mineral, flecked with euhedral pyrite, and filled with a clear, isotropic mineral, probably a zeolite.

The indurated limestone above the basalt in Core 39 is unfossiliferous aragonite flecked with pyrite, with a small amount of calcite $\left(6.5\right.$ mole \% $\left.\mathrm{MgCO}^{3}\right)$. The photomicrographs (Plate 1, Figures 2 and 3) show the carbonates occurring as small ( $0.1 \mathrm{~mm}$ diam.), cloudy, stubby or sub-rounded optically continuous pellets; as clear, fine, stacked or radiating needles surrounding many of the pellets; and as larger $(1-3 \mathrm{~mm})$ bladed or patchy crystals cementing and filling voids in the altered basalt glass inclusion. Optic figures verify that aragonite forms the pellets and bladed crystals. No figures were obtained on the needles. Calcite was not identified optically; only the main calcite peaks appeared, at low intensity, in the diffraction pattern. The pyrite is disseminated fairly regularly along the grain boundaries in clumps up to $0.01 \mathrm{~mm}$. The inclusion is altered to pale green clays, phillipsite, and iron oxides, with some pyrite. The oxides are shown (Plate 1, Figure 3) concentrated into fine bands between the fibrous clays. Smaller altered glass inclusions occur throughout the limestone. The same alteration minerals crust the glassy rind of the basalt. Pyrite in both the limestone and cracks in the sideromelane, plus altered basalt pieces in the limestone, probably mean that the aragonitic limestone directly overlies the basalt.

The ironstone (Plate 1, Figure 4) primarily contains almost submicroscopic orange brown, moderately diffracting goethite, $\mathrm{FeO}(\mathrm{OH})$. Hematite and clays are absent. A patchwork of clouded anhedral calcite crystals $(0.1 \mathrm{~mm})$ quilts the groundmass. Larger, less clouded mosaic patches of interlocking untwinned calcite are irregularly distributed throughout the section. Slight subparallel orientation of the calcite grains suggests bedding. The rock is free of fossils. Rare $0.05-\mathrm{mm}$ euhedral grains of a low birefringent mineral may be zeolites. Similar $0-1 \mathrm{~mm}$ irregular patches may be tiny cavity fillings.

The dark yellow brown clays are calcite-free montmorillonites, seen in smear slides to be clouded with finely divided opaque matter. No thin sections of the clays were prepared.

TABLE 1

Chemical Determinations, Site 183 (All Metals $\mathrm{CaCO}_{3}$-free)

\begin{tabular}{|c|c|c|c|c|c|c|c|c|}
\hline & 1 & 2 & 3 & 4 & 5 & 6 & 7 & 8 \\
\hline $\mathrm{Fe}$ & $17.02 \%$ & $23.8 \%$ & $7.3 \%$ & $17.5 \%$ & $18.00 \%$ & $5.06 \%$ & $44.0 \%$ & $35.1 \%$ \\
\hline $\mathrm{Mn}$ & $5.99 \%$ & $4.16 \%$ & $1.28 \%$ & $4.52 \%$ & $6.00 \%$ & $0.48 \%$ & $0.8 \%$ & $1.5 \%$ \\
\hline $\mathrm{Cu}$ & 870 & 1550 & 560 & 917 & 730 & 323 & 3000 & 8000 \\
\hline $\mathrm{Zn}$ & 437 & 2 & 86 & 358 & 380 & - & - & $2.56 \%$ \\
\hline $\mathrm{Ni}$ & 795 & 257 & 135 & 535 & 430 & 211 & - & - \\
\hline $\mathrm{Co}$ & 167 & 44 & 35 & & & & & \\
\hline $\mathrm{Cr}$ & 33 & 15 & 15 & & & & & \\
\hline $\mathrm{Pb}$ & 181 & 38 & 34 & & & & & \\
\hline $\mathrm{Sr}$ & $1.95 \%$ & & & & & & & \\
\hline $\mathrm{CaCO}_{3}$ & $73.52 \%$ & $32.06 \%$ & & & & & & \\
\hline Organic C & $0.016 \%$ & $0.031 \%$ & & & & & & \\
\hline
\end{tabular}

(1) Site 183 aragonitic limestone; (2) Site 183 goethite ironstone; (3) Site 183 brown clay; (4) average of 11 sediments, Leg 16 (Cronan et al., 1972); (5) average $\mathrm{CaCO}_{3}$-free sediments, East Pacific Rise (Bostrom and Peterson, 1969); (6) average surface pelagic clay (Cronan, 1969); (7) Red Sea amorphous goethite facies (Bischoff, 1969a); (8) Red Sea iron montmorillonite facies (Bischoff, 1969a).

All values as ppm unless indicated as weight $\%$. 
The bluish white nannofossil limestone is calcite and is considered unaffected by metal-enrichment processes. The nannofossils are dated as middle Eocene ( $\sim 50 \mathrm{my}), 12 \mathrm{my}$ younger than the basement age estimated from the inferred position of Site 183 on magnetic anomaly 25 (Heirtzler et al., 1968; Berggren, 1969; Menard and Atwater, 1970).

The clays and goethite-rich ironstone resemble the iron-rich sediments reported from the East Pacific Rise or its flanks (Böstrom and Peterson, 1966, 1969; Böstrom et al., 1970; von der Borch et al., 1971; von der Borch and Rex, 1970; Cook, 1971; Cronan et al., 1972). These reports implied that the sediments may have been enriched in heavy metals via "hydrothermal exhalations" related to zones of volcanism and high heat flow such as the crest of the East Pacific Rise. According to these authors, the Tertiary and other ferruginous sediments were carried away from the rise crest by sea floor spreading. These Pacific sediments however are all iron-rich clays and marls. The aragonitic limestone and clay-free goethite ironstone are facies previously unreported from Pacific ferruginous basal sediments. The ironstone may be a consolidated equivalent of the so-called "goethite amorphous" facies of the Red Sea metalliferrous sediments (Bischoff, 1969a).

\section{Chemistry of the Site 183 Sediments}

Atomic absorption analyses for the elements $\mathrm{Fe}, \mathrm{Mn}, \mathrm{Cu}$, $\mathrm{Zn}, \mathrm{Ni}, \mathrm{Co}, \mathrm{Cr}$, and $\mathrm{Pb}$ were made for sediments from Sites 183 and 192A using Perkin-Elmer Models 303 and 403 Atomic Absorption Spectrophotometers, the latter unit equipped with a deuterium arc background corrector. Tests for matrix effects were made on selected samples using the method of additions, and if discrepancies were noticed, all samples were rerun using standard additions. Runs were calibrated using various USGS rock standards. In addition to metals, analyses for $\mathrm{Ca}, \mathrm{Mg}$, and $\mathrm{Sr}$ were made for the aragonitic limestone. Total carbon, organic carbon, and calculated $\mathrm{CaCO}_{3}$ were determined at DSDP's Sediment Laboratory using a LECO 70 Second Analyzer. These data were used to calculate the metal compositions of the sediments $\mathrm{CaCO}_{3}$ - free. The results of analyses for the Site 183 sediments and a variety of melta-bearing sediments from other locales are given in Table 1, those for Site 192A in Table 2.
Iron, manganese, copper, zinc, and nickel are in good agreement with data from recent and old sediments associated with the East Pacific Rise in terms of both absolute amounts and proportions. The clay is the least metallogenic, but is clearly enriched compared to average surface pelagic clays. Copper is proportionally higher and zinc and nickel proportionally lower in the ironstone than in the limestone. This may reflect a preference of $\mathrm{Zn}$ and $\mathrm{Ni}$ for the sulfide phase compared to the goethite. The sediments are less enriched in almost all elements compared to Red Sea sediments. But like the Red Sea, sediments of contrasting oxidation state and lithology were recovered.

$\mathrm{Sr}$ in the limestone is higher than in typical aragonites formed in seawater. Kinsman (1969), on the basis of experimentally determined partition coefficients, predicted a concentration of $8290 \pm 850 \mathrm{ppm}$ for aragonite precipitated from seawater at $25^{\circ} \mathrm{C}$ in the Bahamas (compared to $9800 \mathrm{ppm}$ actual value, the difference due to organic complexing, according to Kinsman), and $8200 \pm 1100$ for Persian Gulf aragonite (compared to 9590 actual). Reef corals give values of $9781 \pm 300$ in the Bahamas and $7740 \pm 300$ in the Persian Gulf. If the value of $19,500 \mathrm{ppm}$ for the Site 183 aragonite is concentrated in the $\mathrm{CaCO}_{3}$, with none in the sulfides, then the aragonite actually has $25,600 \mathrm{ppm} \mathrm{Sr}$, about 2 to 3 times higher than values predicted or found in the open ocean. Further, the value of $\left(\mathrm{m} \mathrm{Sr}^{2+}\right) /\left(\mathrm{m} \mathrm{Ca}^{2+}\right)$ at Site 183 is 0.059 compared with the value of 0.009 for typical aragonites separated from sea water (Winland, 1969). The value of $\left(\mathrm{mole} \% \mathrm{SrCO}_{3}\right) /$ $\left(\operatorname{mole} \% \mathrm{MgCO}_{3}\right)$ is crucial to the stability of aragonite (Wollast et al., 1971) and must be above 0.25 for aragonite to be stable. At Site 183 the value is 0.61 .

\section{PROBLEM OF THE BASALT CONTACT}

Pillow lavas have been known to form intrusively in soft, wet sediments (Wilson, 1960, p. 100; Garrison, 1972) and the age discrepancy at Site 183 suggests that the chilled basalt might overlie older sediments. An intrusive contact seems plausible considering the peculiar sediments, possibly "baked" limestones, above the basalt. However, the mineralogy of the sediments precludes their having been altered by baking. No high temperature contact metamorphic

TABLE 2

Chemical Determination, Hole $192 \mathrm{~A}, \mathrm{CaCO}_{3}$-free

\begin{tabular}{c|cccccrrr} 
& 1 & 2 & 3 & 4 & 5 & 6 & 7 & 8 \\
\hline \cline { 2 - 9 } $\mathrm{Fe}$ & $4.4 \%$ & $6.2 \%$ & $6.3 \%$ & $7.5 \%$ & $9.4 \%$ & $7.8 \%$ & $6.1 \%$ & \\
$\mathrm{Mn}$ & 936 & 1046 & 1356 & 1345 & 2700 & 3450 & 5460 & 4380 \\
$\mathrm{Cu}$ & 143 & 103 & 136 & 129 & 606 & 31 & 38 & 317 \\
$\mathrm{Zn}$ & 118 & 149 & 162 & 142 & 123 & 100 & 541 & 197 \\
$\mathrm{Ni}$ & 33 & 69 & 129 & 142 & 6 & 58 & 73 & \\
$\mathrm{Co}$ & 28 & 36 & 41 & 50 & 48 & 28 & 69 & \\
$\mathrm{Cr}$ & 20 & 17 & 110 & 78 & 25 & 12 & 12 & \\
$\mathrm{~Pb}$ & 7 & 8 & 9 & 10 & 8 & 4 & 4 & \\
$\mathrm{CaCO}_{3}$ & $12.26 \%$ & $37.67 \%$ & $47.46 \%$ & $42.15 \%$ & $20.22 \%$ & $56.67 \%$ & $51.80 \%$ \\
Organic C & $0.068 \%$ & $0.058 \%$ & $0.058 \%$ & $0.047 \%$ & $0.050 \%$ & $0.045 \%$ & $0.058 \%$ \\
\hline
\end{tabular}

Samples from left to right approach volcanics. (1) 4-2-55, last dark silty clay; (2) 4-2-105; (3) 4-3-126; (4) 4-4-65; (5) 5-0-2; (6) 5-1-66; (7) 5-1-75, at contact with volcanics; (8) 5(CC), iron oxides in basalt crack, 3 trace metals only.

All values as ppm unless indicated as weight $\%$. 
minerals were found. Aragonite and goethite are unstable at elevated temperatures. Faust (1950) heated aragonite at a rate of $12^{\circ} \mathrm{C}$ per minute and found a small endothermic peak at $387^{\circ}$ to $488^{\circ} \mathrm{C}$, marking the transition from aragonite to calcite. The transformation occurs at even lower temperatures with "wet" sediments. At $23^{\circ} \mathrm{C}$ chemically pure aragonite in the presence of pure water transforms into calcite in 100 days (Taft, 1967). At $100^{\circ} \mathrm{C}$ the transformation occurs in 24 hours (Fyfe and Bischoff, 1965 , p. 11). Bischoff (1969b) presented thermodynamic data showing that goethite dehydrates to hematite at $115^{\circ} \mathrm{C}$. Aragonite could not have formed from calcite under the influence of pressure as it is stable only above 5 kilobars (Jamieson, 1953; Clark, 1957). All aragonite found in the oceans is thus metastable. Arguments to be presented imply that the indurated aragonite cementing the limestone and basaltic inclusions formed at the sediment-water interface. Apparently, exposed basalt was losing glass fragments into surrounding lime oozes by erosion.

The explanation for the age discrepancy may lie in a virtually nonexistent sedimentation rate during the early Tertiary documented at Site 192 of Leg 19. The 23 meters above basalt that may have iron-enriched sediments could represent the entire sediment column for the 12 my gap using Site 192 sedimentation rates for the same interval of time. However, alkali basalts such as at Site 183 are typical of seamount related volcanism rather than ridge crest volcanism which produces low potash oceanic tholeiites (Engel and Engel, 1970). Site 183 lies between Derickson and Sirius seamounts, which are only $90 \mathrm{~km}$ apart. Thus the iron-rich sediments may not correlate with any rise crest sediments but may overlie them.

\section{PROBLEM OF THE ARAGONITE}

Aragonite is a distinct anomaly for deep-sea sediments. Its most typical marine occurrence is in shallow waters associated with reefs and shallow banks. Many corals and pelagic organisms construct aragonite septa or shells. In these environments, however, aragonite is usually not a cementing agent (Friedman, 1964). It is not found in ancient reef limestones because it converts to calcite under conditions of diagenesis. Its proportion in limestones decreases with their geologic age. Strontium is usually high in aragonite, being more readily accepted as a $\mathrm{Ca}$ substitute than in calcite. Its content in ancient limestones diminishes with their age proportionally as aragonite converts to calcite under conditions of diagenesis (Bausch, 1968). However, aragonite is more stable with appreciable quantities of $\mathrm{Sr}$ in the lattice than without (Zeller and Wray, 1956; Wray and Daniels, 1957), so that high-Sr aragonites resist diagenetic inversion to calcite. This perhaps accounts for the persistence of aragonite at Site 183 .

Aragonite is almost never found among lithified sediments in the deep-marine realm, however, and when it does occur, it is in very subordinate amounts compared to calcite and high-Mg calcite (Friedman, 1965). This is partly because aragonite formed in surface water dissolves more readily than calcite as it settles to the bottom. Where the calcite compensation depth is at about 4500 meters, aragonite begins to disappear from ocean floor sediments at about 2700 and is practically absent below 3600 meters
(Murray and Hjort, 1912). Dissolution during descent and conversion to calcite under "wet" conditions thus both operate against aragonite stability at great depth.

Seawater is undersaturated with $\mathrm{CaCO}_{3}$ at a depth of only a few hundred meters (Peterson, 1966; Berger, 1967, 1970). Thus, for aragonite to form at all it must do so in surface waters, or special conditions must exist in some part of the water column or in the sediments. The case most comparable to the Site 183 limestone is from the Red Sea. Narrow $(5 \mathrm{~mm})$ indurated layers with 50 to 90 per cent aragonite have been found in otherwise poorly consolidated deep-water Red Sea cores (Gevirtz and Friedman, 1966). These layers are thinner than the Site 183 limestone and have abundant fossils (Pteropoda). In the Red Sea layers, aragonite makes up many of the fossils. It also occurs as radial, syntaxial fibers in the fossil chambers and in pisolites, and forms the cement between them. Normally shallow-water faunas forming aragonitic shells have been swept into deeper waters and replaced by calcite or dissolved. Friedman (1965) reports that despite an existing supply of aragonitic tests from dead pteropods, tests are absent below 956 meters. Aragonitic tests are absent from the unconsolidated portions of the cores with the indurated aragonite layers, and even the deeper layers are pitted and crumbly, indicating dissolution will alter these, too, with time. Aragonite found forming a cement in the indurated layers requires that special conditions favoring inorganic aragonite precipitation alternated in the water column with more normal (dissolution) conditions operating now. Special conditions must also have prevailed at Site 183 when the aragonite cementing the inclusions and making up the mineral grains was formed.

The Site 183 limestone lacks fossils, and has, instead, small needles and pellets. Needle-like aragonite is found in calcareous muds on shallow banks (Friedman, 1965) where aragonite is not a cementing mineral, except in association with evaporites (Gevirtz and Friedman, 1966). Needles and pellets of aragonite, a close analog to the Site 183 material, were precipitated inorganically from seawater at $16^{\circ} \mathrm{C}$ and $30^{\circ} \mathrm{C}$ in laboratory experiments by Kinsman and Holland (1969). This same report presented data showing that aragonite is the only polymorph of $\mathrm{CaCO}_{3}$ precipitated above $30^{\circ} \mathrm{C}$ from seawater. Oxygen and carbon isotope data from the Dead Sea support an origin for aragonite from warm, hypersaline brines formed during periods of strong surface evaporation (Friedman, 1966). In the Red Sea, such brines carry heavy metal complexes in solution. Bottom water temperatures in the Dead Sea have been recorded from $33^{\circ} \mathrm{C}$ to $36^{\circ} \mathrm{C}(\mathrm{Neev}, 1964)$ and temperatures from $44^{\circ} \mathrm{C}$ to $56^{\circ} \mathrm{C}$ characterize the deeps of the Red Sea (Swallow and Creese, 1965). Gevirtz and Friedman concluded that the interbedded hard aragonite layers reflect cyclical changes in which "temperature and salinity have increased and decreased at the bottom of the Red Sea." There is thus a strong argument by analogy that the Site 183 aragonite precipitated inorganically from warm brines enriched in heavy metals, as were the aragonite layers and metalliferous sediments in the Red Sea. Milliman and others (1969) argued that some of the indurated aragonite layers in the Red Sea were formed during lowered sea level during the Pleistocene when high evaporation rates combined with 
even more restricted circulation to produce hypersaline conditions. This does not negate the arguments of Gevirtz and Friedman, and could not account for the Site 183 pyritiferous aragonite, formed in the open ocean.

Aragonite vein fillings in marine manganese nodules have been reported from the Blake Plateau (McFarlin, 1967). Oxygen isotope analysis suggests that the aragonite formed at $4^{\circ} \mathrm{C}$ to $5^{\circ} \mathrm{C}$. The Site 183 limestone has cemented pellets and needles, however, which are features of a sediment. Complete enclosure of the thin $(1-3 \mathrm{~mm})$ veins in the manganese nodules implies that they formed in a restricted microenvironment from solutions strongly influenced by diffusion and the kinetics of a peculiar substrate. The association with heavy metal deposits, however, seems a common factor in deep-sea aragonite formation. In all cases peculiar conditions in the solutions compared to sea water are required or inferred. The best analog to the Site 183 sediments invokes warm, metal-bearing brines. The Blake Plateau aragonite may raise doubts that the brines were warm, but that the aragonite formed from something other than seawater cannot be doubted. The $\mathrm{Sr}$ and metal enrichment require it. How warm they were is a less important question than how they formed in the first place.

\section{CONDITIONS OF FORMATION OF METAL-RICH SOLUTIONS}

In the Pacific, no hot saline brines have been found, nor is it easy to visualize how they could persist in contact with cold bottom waters and dispersing currents even in sea floor basins of restricted circulation. Restricted circulation and special climatic and geologic factors favor the formation of Red Sea brines from surface waters (Craig, 1969; Milliman and others, 1969) and promote the spectacular metal enrichment not yet equalled by an oceanic occurrence. In the open ocean, the only likely source of heat and metals is volcanic. Corliss (1970), using high-precision neutron activation analysis, concluded that $\mathrm{Fe}, \mathrm{Mn}, \mathrm{Co}, \mathrm{Cu}, \mathrm{Ga}, \mathrm{Pb}$, and the rare earth elements are concentrated in residual solutions during slow crystallization of basalts and "are mobilized by dissolution - in seawater introduced along contraction joints forming in the late stages of cooling". White (1968), integrating field and experimental data, particularly on fluid inclusions, stipulated that ore constituents, whatever their source, must dissolve in a hydrous phase, a Na-Ca-C1 brine in the cases he discussed (including the Salton Sea and Red Sea deposits). Helgeson (1964) states that "most hydrothermal solutions are alkali chloride-rich electrolyte solutions containing predominant $\mathrm{Na}$ and $\mathrm{C} 1$, lesser amoungs of $\mathrm{K}$ and $\mathrm{Ca}$, small amounts of $\mathrm{SO}_{4}^{2+}, \mathrm{CO}_{3}^{2+} \mathrm{HCO}_{3}^{+}, \mathrm{Li}, \mathrm{Rb}, \mathrm{Cs}$ and other minor constituents...." (p. 80). Corliss' model contends that the brines responsible for iron-rich oceanic sediments filtered into cooling lavas and dissolved or leached constituents released during deuteric alteration, especially of olivines. Hypersaline brines would thus form from concentration and distillation of seawater salts in cracks, fissures, and subjacent magma chambers. The conditions described by White and Helgeson are reflected in the metal and $\mathrm{Sr}$ enrichment of the Site 183 sediments, while aragonite precipitation implies carbonate saturation, certainly not a feature of normal bottom water. Pyrite demonstrates sulfur enrichment in the same brines. Bonatti, et al., (1972) report Fe-Mn deposits associated with submarine basalts now exposed in the northern Afar Rift of Eastern Ethiopia. Some of the Mn-rich layers are also enriched in $\mathrm{Ba}$ and $\mathrm{Sr}$, with strontiobarite crystals containing up to 12 per cent $\mathrm{SrSO}_{4}$ in solid solution. While these are considerably more exotic than the Site 183 sediments, the report again relates them to "submarine exhalative activity" and brines "injected through the sea floor."

The formation of iron-rich sediments at Site 183 may have been favored by the inferred low sedimentation rate at that time. At best, hot brines could only have existed sporadically as the site was probably some distance from the Kula Rise and experiencing relatively small-volume seamount-related volcanism. If the organic sedimentation rate had been higher, episodic brine deposits would have been diluted and probably reworked by benthic organisms. This may be why direct evidence for hot brines has not been found among East Pacific Rise-related sediments. The Site 183 clays and ironstone are certainly related to the same processes that produced the aragonitic limestone; arguments that they could have formed from normal sea water during the period of low sedimentation rate run afoul of the facies diversity and of metal-enrichment greater than in average Pacific pelagic clay (Table 1). It may be that Site 183 fortuitously cored near a submarine fumarolic vent and that the crucial aragonite layer extends perhaps only a few meters in any direction.

\section{IRON-RICH SEDIMENTS AND VOLCANICS FROM SITE 192}

Nearly a kilometer of silts, clays, and diatomaceous oozes was cored from Holes 192 and 192A atop Meiji Guyot in the northwest Pacific before reaching a series of carbonates and dark gray or grayish green sands, silts, and clays derived from Meiji Guyot itself. These immediately overlie five meters of red brown clays interbedded with white and yellow nannofossil chalks, which in turn overlie extrusive alkali basalt pillow lavas. Sanidine appears in the X-ray patterns of the last dark silty clay and in the upper meters of the red sediments. It is also found as cores in plagioclase crystals in diabasic portions of the cored volcanics. High-temperature alkali feldspar occurs as phenocrysts and groundmass in volcanic rocks of the alkalic series normally found on oceanic islands and seamounts. Authigenic K-feldspar forms in sediments in alkaline environments (Hay, 1963) where it often replaces the calcic cores of plagioclase crystals. Bass and others (in prep) report it replacing calcic plagioclase cores in tholeiitic basalt cored during DSDP Leg 17. Whether the Hole 192A sanidine is magmatic or authigenic (possibly both), it is not found in the overlying hemipelagic sediments derived from nearby island arcs, and was probably largely derived from weathering of the local volcanics.

A chalk interval separates the last dark silty clays from the first red sediment, and several chalky intervals and minor ash layers are encountered before reaching the volcanics. Reworking of the sediments by organisms has partially mixed the white chalks and red sediments. The red sediments and last dark silty clay are montmorillonite, locally free of carbonates, with some sanidine in places. 
The volcanics are described in detail in the site chapter and in the chapter on basalts (Stewart and others, this volume). They are alkali basalt pillow lavas, submarine eruptives typical of small volume late-stage differentiates erupted during the waning stages of volcanism on oceanic islands and seamounts (Engel and Engel, 1970). In this case, eruption occurred after wave truncation had reached the central portions of the guyot and after submergence. Graded dark silts and clays above the red sediments and some shallow-water fossil debris in carbonates associated with the clays imply that wave truncation was still active elsewhere on the guyot. A wave-planed terrace might underlie the sediments and extrusive lavas of Hole 192A. The several flow units of the volcanics are surprisingly diverse mineralogically; some are dominated by intermediate plagioclase and pale salitic clinopyroxenes, others by sodic feldspars and purplish pyroxenes. This diversity suggests small volume flows, possibly from different vents. Heat sources for potential hot brines were thus meager and infrequent.

\section{CHEMISTRY OF SEDIMENTS, HOLE 192A}

Table 2 shows metal concentrations $\left(\mathrm{CaCO}_{3}\right.$-free) for several sediment samples including the last dark silty clay and the interval immediately above the volcanics. At least one sample per section was taken, all from 5 to 10 grams of red clays. The per cent $\mathrm{CaCO}_{3}$ is also shown in Table 2 .

The data show a steady increase and clear enrichment of $\mathrm{Mn}$ as the volcanics are approached, but none of the other elements except $\mathrm{Zn}$ are most enriched just above basalt. $\mathrm{Fe}$ and $\mathrm{Cu}$ are most enriched over two meters above basalt, both in the same sample. The other elements do not show striking enrichment and are not clearly covariant with $\mathrm{Fe}$, $\mathrm{Mn}, \mathrm{Cu}$ or $\mathrm{Zn}$. Still there are factors of twenty variation in $\mathrm{Cu}$ and $\mathrm{Ni}$; five in $\mathrm{Mn}, \mathrm{Zn}$, and $\mathrm{Cr}$; and two in $\mathrm{Fe} . \mathrm{Mn}$ and $\mathrm{Zn}$ seem covariant as do $\mathrm{Fe}$ and $\mathrm{Cu}$, the same relations for the different facies at Site 183. The numbers are of the same order as those of the average surface pelagic clay cited by Cronan (1969), for which metal sources ranging from dissolution from continental rocks to volcanic exhalates have been proposed (Arrhenius, 1963). Following Goldberg and Arrhenius (1958), Arrhenius (1963, p. 672) suggests that "manganese is removed from the bottom water by catalytic oxidation of manganous iron by colloidal ferric hydroxide at the sediment-water interface."

The Hole 192A sediments, however, are closely related to the altered volcanics they overlie. There is strong field and textural evidence that the sediments and the metals they contain were derived possibly entirely, but at least in part, from processes of alteration and weathering (halmyrolysis) of the volcanics.

\section{ALTERATION OF THE VOLCANICS}

The several meters of volcanics represent several flows, the largest 8.4 meters thick with well developed diabasic, even cumulate textures. Cracks, up to $3 \mathrm{~cm}$ wide riddle the entire core of basalts. In the largest flow these attain the aspect of vertical and horizontal joints spaced only a few centimeters or tens of centimeters apart. All these cracks, plus the spaces between flows, have clearly been channels for fluxing solutions. Alteration is most intense in zones 2 to $4 \mathrm{~cm}$ to either side of cracks. Prominent stains of reddish iron oxides parallel the cracks in the volcanics in these intensely altered zones, which can comprise up to 50 per cent of a given section. The narrow cracks are filled with crystalline calcite. The larger cracks are filled with micritecemented volcanic sands, or with milky cryptocrystalline calcite replacing nannofossil ooze. Many cracks have patches or spongelike growths of green montmorillonite, which are often associated with deep red brown oxides which, with milky replacement calcites, frequently fill the centers of cracks. The iron oxide crack fillings may be only faint stains, but are sometimes concentrates of almost pure iron oxides up to a centimeter wide.

One such concentrate was sampled from the core catcher of Core 5, 8.25 meters into the volcanics. Two mineral fractions could be separated. The first, which was orange red, readily suspended in water and easily dissolved. Only highly amorphous scattering appeared on the X-ray pattern. These features are typical of goethite or other iron hydroxides. The second fraction resisted suspension and rapid solution in concentrated $\mathrm{HC1}$. It was dark brown to black, slightly magnetic, and gave some low peaks suggestive of hematite when X-rayed. Heating in $\mathrm{HCl}$ left an insoluble residue of less than 4 per cent, mostly green clays, but with minor plagioclase and pyroxene, all minerals of the surrounding volcanics. $\mathrm{Mn}, \mathrm{Cu}$, and $\mathrm{Zn}$ proved to be fairly high in the total concentrate, as shown for sample 192A-5(CC) in Table 2, and quite comparable to levels in the sediments, but low considering that the sediments are mostly clays while the concentrate is almost pure metal oxides, mostly Fe.

The argument that clays and metals of the sediments came from the volcanics is supported by petrographic evidence. Large portions of the glassy and diabasic portions have been replaced by calcite, clays and, in the most altered zones next to cracks, reddish iron oxides. Plate 2, Figure 1, shows clumps of green clays and calcite filling an irregular void in a glassy margin near the top of the volcanics. Plate 2, Figure 2 shows ovoid calcite clusters, orange clays, and iron oxides in a void in a diabasic portion of the largest flow. This had to replace a previously intersertal or even coarse crystalline part of the rock since this diabase is not amygdular in less altered portions. In the diabases, essentially all the material between mineral grains is given over to calcite or botryoidal clays often stained red with iron oxides (Plate 2, Figure 3).

With so much of the rock replaced by clays and calcite, with clear evidence of clays growing in cracks and vesicles, and with concentrates of iron oxides bearing excess $\mathrm{Mn}, \mathrm{Cu}$, and $\mathrm{Zn}$, there is ample evidence that fluxing of the volcanics by solutions stripped them of clays and metals to form the main part of the overlying red sediments. This was essentially a low temperature process, consistent with the formation of clays, goethite, and calcite.

At one point in the volcanics, a crack with a core of iron oxides has been broken and then filled with micrite cemented sands. This places the alteration and concentration of metals early in the history of Site 192 when mobile sediments local to Meiji Guyot could still drift into cracks.

Irregularities in the metal concentrations in the sediments are difficult to explain. The highest concentration 
for all metals might have been just above the basalt if fluxing of solutions through immobile sediments had occurred. The variations may reflect variations in the geometry of sediments and volcanics, slumping, biologic reworking with selective concentration, changes in sedimentation rate, or differences in oxidation state from place to place in the sediment pile.

The driving mechanism for circulating fluids can only be surmised. The most likely cause is a locally high thermal gradient, perhaps the result of a nearby subjacent magma chamber which may also be the source of the cored volcanics. Seawater having access to such a magma chamber could well concentrate residual metal constituents which would be deposited on fluxing through overlying rocks and sediments. But the solutions altering the rocks were clearly of low temperature by the time they reached the surface. There is no absolute necessity to achieve striking metal concentrations in the circulating fluids, whatever their source. Constant fluxing coupled with the ion exchange properties of clays and oxides could increase the concentration of metals in the volcanics or the sediments far beyond the levels precipitating from a given solution at any one time. The effect of the percolating fluids, in an environment with carbonate sediments, is to attack the volcanics, replacing large portions of them with clays and calcite. This by itself requires mobilization of whatever was replaced silicates and metals, later seen as ferruginous clays.

\section{IMPLICATIONS OF IRON-ENRICHED SEDIMENTS AT SITES 183 AND 192 FOR OTHER LOCALITIES}

Iron-rich sediments at Sites 183 and 192 have been related to one basic process, the concentration of metals into percolating fluids, $\mathrm{Na}-\mathrm{Ca}-\mathrm{C} 1$ rich brines derived largely from seawater. Brines, possibly warm $\left(30^{\circ} \mathrm{C}\right.$ ?), rich in $\mathrm{Sr}$ and metals, poured onto the sea floor at Site 183 to form at least some of the special sediments there. At Site 192 a combination of syngenetic and diagenetic processes related to alteration of volcanics seems the most likely source for the red clays. Both cases demonstrate that ferruginous sediments need not be related to oceanic rises. It is thus risky to correlate metal-rich sediments with any timetransgressive sequence formed at a rise, especially if alkaline volcanic rocks lie beneath the sediments. The sediments and the volcanics may postdate rise-produced materials and overlie them.

The model proposed for the Site 192 sediments could apply to red basal clays and marls elsewhere in the oceans. This would eliminate the need for and explain the lack of metal-rich brines, hot or otherwise, in the oceans above rises or elsewhere. Low temperature processes could act long after a particular section of sea floor drifted away from its parent rise crest. However, rock alteration and hydrothermal action are especially active near rise crests (Anderson, 1972), so that the association of basal metallogenic sediments with crestal activity is probably generally valid. The Site 183 sediments, however, underscore the periodic presence of ocean-floor brines and give hope that more spectacular basal metal-bearing sediments will be cored in the open ocean.

\section{ACKNOWLEDGMENTS}

The writer would like to thank $\mathrm{Mr}$. and Mrs. R. DeHaven, for skillful thin section preparations, and J. Greenslate, J. Pine, R. LaBorde, and G. Bode for assistance with the analytic work. John Whetten and Wolfgang Berger reviewed an early draft. Katie Bertine and members of the SIO Marine Chemistry Seminar made some very helpful suggestions.

\section{REFERENCES}

Anderson, Roger, 1972. Petrologic significance of low heat flow on the flanks of slow-spreading mid-ocean ridges. Bull. Geol. Soc. Am. 83, 2947.

Arrhenius, G., 1963. Pelagic sediments. In The Sea. M. N. Hill (Ed.). New York, Wiley Interscience. 3, 655.

Bass, M. N., Moberly R., Rhodes, J. M., Shih, C. and Church, S. E., in preparation. Volcanic rocks, Leg 17. In Winterer, E. L., Ewing, J. I. et al. Initial Reports of the Deep Sea Drilling Project, Volume XVII. Washington (U.S. Government Printing Office).

Bausch, W. M., 1968. Outlines of distribution of strontium in marine limestones. In Recent Developments in Carbonate Sedimentology in Central Europe. German Müller and G. M. Friedman (Eds.). New York, SpringerVerlag, Inc., 106.

Berger, W. H., 1967. Foraminiferal ooze solution at depths. Science. 156, 383. 1970. Planktonic Foraminifera, selective solution and the lysocline. Marine Geol. 8, 111.

Berggren, W. A., 1969. Cenozoic chronostratigraphy, planktonic foraminiferal zonation, and the radiometric time scale. Nature. 224, 1072.

Bischoff, J. L., 1969a. Red Sea geothermal brine deposits, their mineralogy, chemistry and genesis. In Hot Brines and Recent Heavy Metal Deposits of the Red Sea. E. T. Degens and D. A. Ross (Eds.). New York, SpringerVerlag, 368.

— 1969 b. Geothite-hematite stability relations with relevance to sea water and the Red Sea brine system. In Hot Brines and Recent Heavy Metal Deposits of the Red Sea. E. T. Degens and D. A. Ross (Eds.). New York (Springer-Verlag, Inc.), 402.

Bonatti, E., Fisher, D. E., Joensuu, O., and Rydell, H. S., 1972. Iron-manganese barium deposit from the Afar Rift (Ethiopia). Abst. presented at Conference/Workshop on Ocean Manganese Deposits. Lamont-Doherty Geological Observatory of Columbia University, New York.

Böstrom, K. and Peterson, M.N.A., 1966. Precipitates from hydrothermal exhalations of the East Pacific Rise, Econ. Geol. 61, 1258.

1969. The origin of aluminum-poor ferromanganoan sediments in areas of high heat flow on the East Pacific Rise. Mar. Geol. 7, 427.

Böstrom, K., Peterson, M.N.A., Joensuu, O., and Fisher, D.E., 1970. Aluminum-poor ferromanganoan sediments on active oceanic ridges. J. Geophys. Res. 74(12), 3261.

Clark, S.P., Jr., 1957. A note on calcite-aragonite equilibrium. Am. Mineralogist, 42, 564.

Cook, H.E., 1971. Iron- and manganese-rich sediments overlying basaltic basement, Equatorial Pacific Leg 9, Deep Sea Drilling Project. Geol. Soc. Am. Ann. Mtgs. Abstr. 530.

Corliss, J.B., 1970. Mid-ocean ridge basalts: 1 . The origin of submarine hydrothermal solutions. Unpublished Ph.D. Thesis, University of California, San Diego. 
Craig, H., 1969. Geochemistry and origin of the Red Sea brines. In Hot Brines and Recent Heavy Metal Deposits in the Red Sea, E.T. Degens and D.A. Ross (Eds.), (New York Springer-Verlag, Inc.) 208.

Cronan, D.S., 1969. Average Abundances of $\mathrm{Mn}, \mathrm{Fe}, \mathrm{Ni}$, $\mathrm{Co}, \mathrm{Cu}, \mathrm{Pb}, \mathrm{Mo}, \mathrm{V}, \mathrm{Cr}, \mathrm{Ti}$ and $\mathrm{P}$ in Pacific pelagic clays. Geochim, et Cosmochim. Acta. 33, 1562.

Cronan, D.S., van Andel, T.H., Heath, G. Ross, Dinkelman, M.G., Bennett, R.H., Bukry, David, Charleston, Santiago, Kaneps, Ansis, Rodolfo, K.S., and Yeats, R.S., 1972. Iron-rich basalt sediments from the eastern equatorial Pacific: Leg 16, Deep Sea Drilling Project, Science. 175(1), 61 .

Engel, A.E.J. and C.G. Engel, 1970. Mafic and ultramafic rocks. In The Sea. A. E. Maxwell (Ed.). New York (Wiley Interscience). 4 (Part I), 465.

Faust, G.T., 1950. Thermal analysis studies on carbonates: 1. Aragonite and calcite. Am. Mineralogist, 35, 207.

Friedman, G.M., 1964. Early diagenesis and lithification in carbonate sediments. J. Sed. Pet. 34, 777.

Friedman, G.M., 1965. Occurrence and stability relationships of aragonite, high-magnesian calcite, and low magnesian calcite under deep-sea conditions, Bull. Geol. Soc. Am. 76, 1191.

Friedman, G. M., 1966. On the origin of aragonite in the Dead Sea. Israel J. Earth Sciences. 14, 79.

Fyfe, W.S. and Bischoff, J.L., 1965. The calcite-aragonite problem. In Dolomitization and Limestone Diagenesis: a Symposium. L.C. Pray and R.C. Murray, Eds., Soc. Econ. Paleontologists Mineralogists Spec. Publ., 13, 3 .

Garrison, R.E., 1972. Relations between pillow basalts and pelagic limestones, Olympic Peninsula, Washington. Geol. Soc. Am. Cordilleran section, 68th Annual Meeting. 4(3), 161,

Gevirtz, Joel L. and Friedman, G.M., 1966. Deep-sea carbonate sediments of the Red Sea and their implications on marine lithification. J. Sed. Pet. 36, 143.

Goldberg, E.D. and Arrhenius, G., 1958. Chemistry of Pacific pelagic sediments. Geochim. et Cosmochim Acta. 13, 153 .

Hay, R.L., 1963. Zeolites and zeolitic reactions in sedimentary rocks. Geol. Soc. Am. Spec. Paper 85, 130.

Heirtzler, J.R., Dickson, G.O., Herron, E.M., Pitman, W.C. the third, and LePichon, X., 1968. Marine magnetic anomalies, geomagnetic field reversals, and motions of the ocean floor and continents. J. Geophys. Res. 73, 2119.

Helgeson, Harold C., 1964. Complexing and hydrothermal one deposition: International Series of Monographs on Earth Sciences, 17, New York (MacMillan).

Jamieson, J.C., 1953. Introductory studies of high-pressure polymorphism to 24,000 bars by X-ray diffraction with some comments on calcite, 2. J. Geol. 65, 334.
Kinsman, D.J.J., 1969. Interpretation of $\mathrm{Sr}^{+2}$ concentrations in carbonate minerals and rocks. J. Sed. Pet. 39, 486.

Kinsman, D.J.J., and Holland, H.D., 1969. The coprecipitation of cations with $\mathrm{CaCO}_{3}$ IV: The co-precipitation of $\mathrm{SR}^{+2}$ with aragonite between $16^{\circ}$ and $96^{\circ} \mathrm{C}$, Geochim. et Cosmochim. Acta. 33, 1.

McFarlin, Peter F., 1967. Aragonite vein fillings in marine manganese nodules, J. Sed. Pet. 37, 68.

Menard, H.W., and Tanya Atwater, 1970. Changes in the direction of sea floor spreading. Nature. 219, 463.

Milliman, J.D., Ross, D.A., and Teh-Lung, K., 1969. Precipitation and lithification of deep sea carbonates in the Red Sea. J. Sed. Pet., 39, 724.

Murray, J. and Hjart, J., 1912. The Depths of the Oceans, London (Macmillan).

Neev, David, 1964. Geologic processes in the Dead Sea. Ph.D. Diss., Hebrew University, Jerusalem.

Peterson, M.N.A., 1966. Calcite: rates of dissolution in a vertical profile in the Central Pacific. Science. 154, 1542 .

Swallow, J.C., and Creese, J., 1965. Hot salty water at the bottom of the Red Sea, Nature. 205, 165

Taft, W.H., 1967. Modern carbonate sediments. In Carbonate Rocks. Origin, Occurrence and Classification. G.V. Chilingar, H.J. Bissell, and R.W. Fairbridge, Eds., Amsterdam, (Elsevier). 29.

von der Borch, C.C., and Rex, R.W., 1970. Amorphous iron-oxide precipitates in sediments cored during Leg 5. In McManus, D.A., Burns, R.E., et al., 1970. Initial Reports of the Deep Sea Drilling Project, Volume V. Washington (U.S. Government Printing Office) 541.

von der Borch, C.C., Nesteroff, W.D., and Galehouse, J.S., 1971. Iron-rich sediments cored during Leg 8 of the Deep Sea Drilling Project. In Tracey, Sutton, G.H., et al., 1971. Initial Reports of the Deep Sea Drilling Project, Volume VIII, Washington (U.S. Government Printing Office), 829.

White, D.E., 1968. Environments of generation of some base metal ore deposits, Econ. Geol. 63, 301.

Wilson, M.E., 1960. Origin of pillow structure in early Precambrian lavas of western Quebec, J. Geol. 68, 97.

Winland, H.D., 1969. Stability of calcium carbonate polymorphs in warm, shallow seawater, J. Sed. Pet. 39, 1579.

Wollast, R., DeBouverie, D., and D'uvigneaud, P.H., 1971. Influence of $\mathrm{Sr}$ and $\mathrm{Mg}$ on the stability of calcite and aragonite. In Carbonate Cements, O.D. Buker Ed., Baltimore (John Hopkins Press) 274.

Wray, J.L., and Daniels, F., 1957. Precipitation of calcite and aragonite, J. Am. Chem. Soc. 792031.

Zeller, E.J., and Wary, J.L., 1956. Factors influencing precipitation of calcium carbonate. Am. Assoc. Petrol. Geologists Bull. 40, 140. 



\section{PLATE 1}

Figure 1 Pyrite and zeolite crack fillings in glassy margin of basalt, Site 183. Field width $5 \mathrm{~mm}$. Plane-polarized light.

Figure 2 Aragonitic limestone, Site 183, showing pellets with ragged edges and fine needles replacing (?) them in places. Dark specks are pyrite. Field width $1 \mathrm{~mm}$. Plane-polarized light.

Figure 3 Basalt fragment in aragonitic limestone cemented by aragonite in cracks. The fine banding of the basalt suggests palagonite, but the fragment is now pale green with fine opaque banding. Field width $5 \mathrm{~mm}$. Plane-polarized light.

Figure 4 Goethite ironstone, mostly red iron oxides, here black, with patches of calcite. Field width $5 \mathrm{~mm}$. Plane-polarized light. 


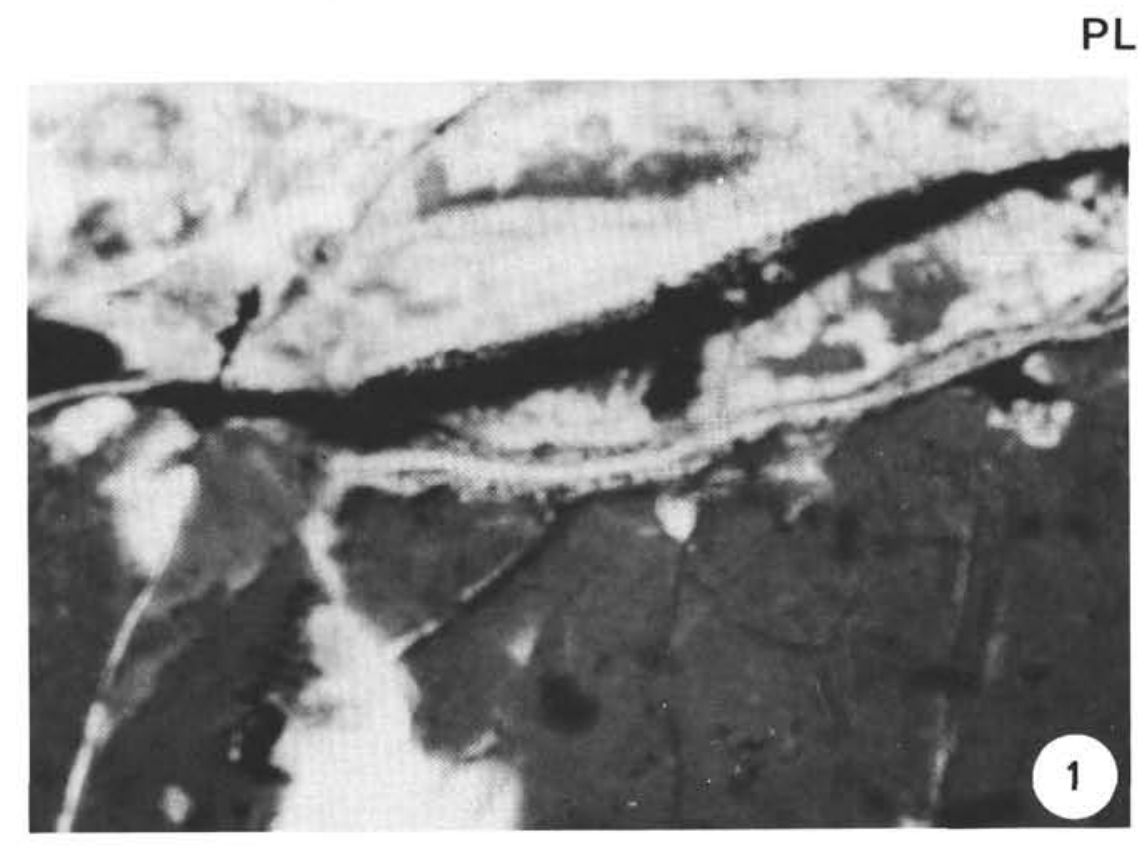

Plate 1
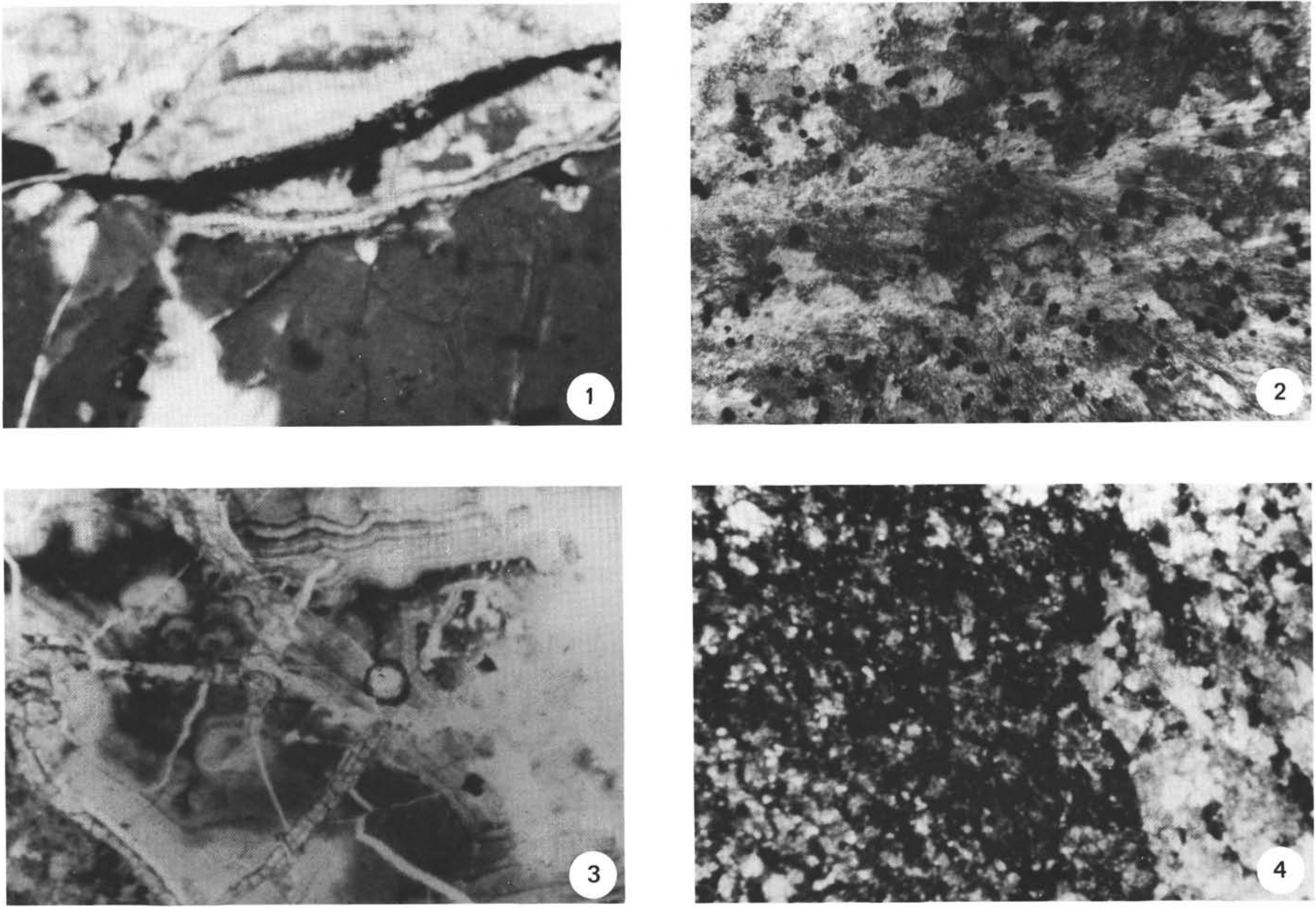


\section{PLATE 2}

Figure 1 Marginal clump-like clays lining irregular cavities in basalt glass, Hole 192A. The gray material is actually green montmorillonite as is the clear fibrous mineral. Field width $1 \mathrm{~mm}$.

Figure 2 Ovoid calcite, orange clays (small specks), and iron oxides (center) replacing diabasic material. Field width $2 \mathrm{~mm}$. Plane-polarized light.

Figure 3 Botryoidal clays stained almost opaque with iron oxides. Field width $1 \mathrm{~mm}$. Plane-polarized light. 


\section{PLATE 2}
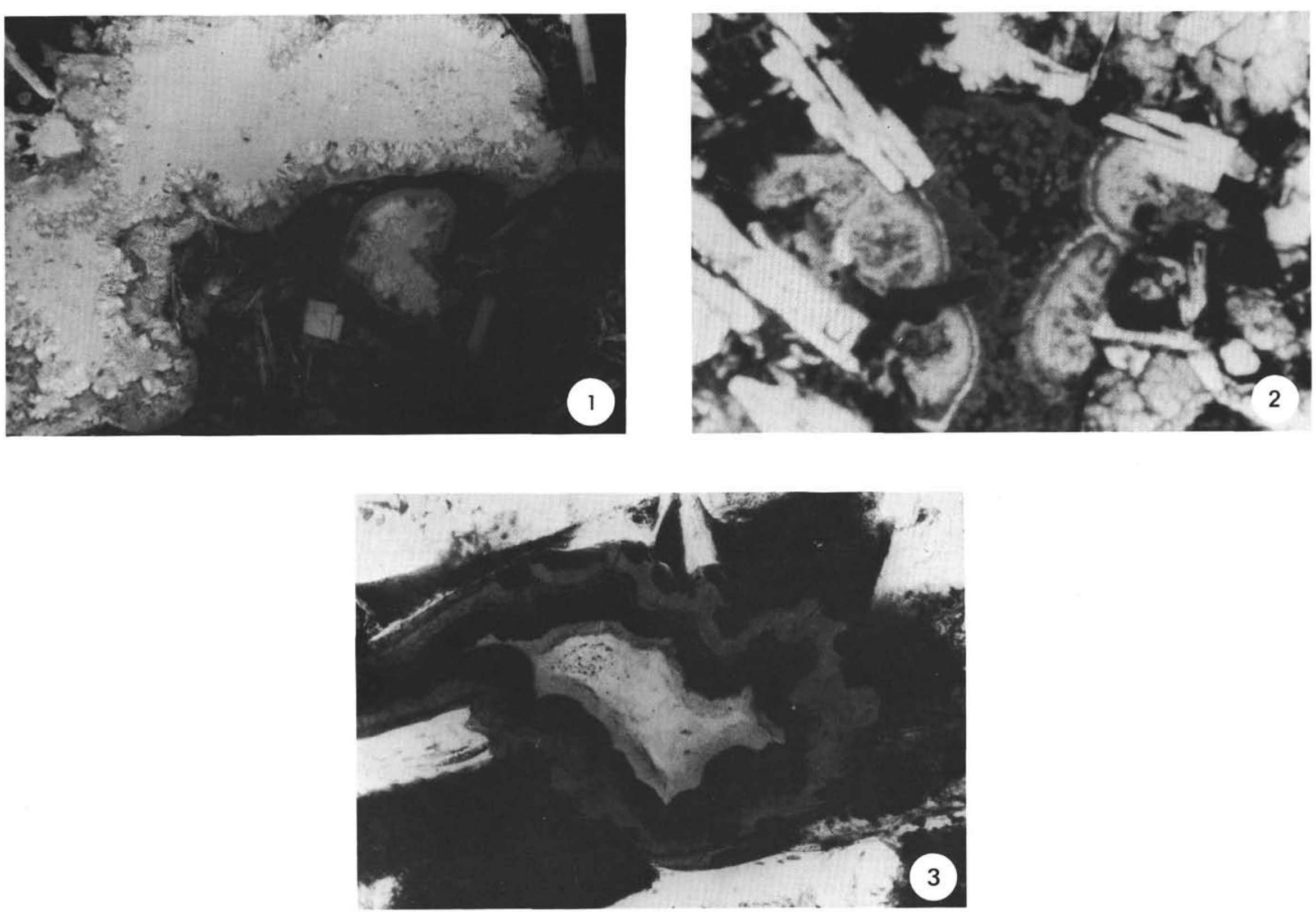